\title{
Turma Recursal da Fazenda Pública do Paraná como locus de formação de jurisprudência e o dever de publicação do voto divergente
}

Small Claim Court of Exchequer of the Paraná State and the obligation of publishing it's dissident opinions

Heloisa Führ Bonamigo

Universidade Federal do Paraná, Curitiba, Paraná, Brasil

\section{Leonardo Catto Menin}

Universidade de São Paulo, Curitiba, Paraná, Brasil

\begin{abstract}
Resumo: O presente trabalho tem por escopo analisar e debater o entendimento jurisprudencial adotado pela Turma Recursal da Fazenda Pública do Estado do Paraná no sentido da não obrigatoriedade de publicação dos votos divergentes quando o resultado dos julgamentos por ela realizados se dá por maioria dos votos. Propõe-se, diante das peculiaridades do rito dos Juizados Especiais da Fazenda Pública, a compreensão da Turma Recursal como locus de formação de jurisprudência, através da qual ocorre o fechamento hermenêutico do sistema jurídico e a fixação de parâmetros de atuação para os jurisdicionados, o que só é possível quando há publicidade nas razões de divergência entre os magistrados.
\end{abstract}

Palavras-chave: Juizado Especial da Fazenda Pública; jurisprudência; voto divergente.

\begin{abstract}
This paper aims to analyze and debate the jurisprudential understanding adopted by the Small Claim Court of Exchequer of the Paraná State. The Court has settled that it is not mandatory to publish its dissident opinions when the result of the claims is not unanimous. The paper advocates that the Small Claim Court of Exchequer is a peculiar locus of construction of jurisprudence, due to the particularities of the procedure occurred in this special jurisdiction. The Courts decisions plays a role of guidance for the citizens and hermeneutical closure of the juridic system, which is only possible when the dissident opinions are made public.
\end{abstract}

Keywords: Small Claim Court of Exchequer; jurisprudence; dissident opinion. 
Sumário: 1. Introdução; 2. Jurisdição no Estado Constitucional e o valor segurança jurídica; 3. Formatação institucional, publicidade e segurança jurídica; 4. Turma Recursal da Fazenda Pública, jurisprudência e publicação do voto divergente; 5. Conclusão; 6. Referências bibliográficas.

\section{Introdução}

No âmbito do Tribunal de Justiça do Estado do Paraná, seguindo orientação jurisprudencial traçada pelo Superior Tribunal de Justiça, firmou-se entendimento quanto à competência absoluta dos Juizados Especiais da Fazenda Pública para as causas cujo valor seja de até sessenta salários-mínimos, independentemente da complexidade fática ou jurídica da lide.

Trata-se de situação que, diante de peculiaridades da própria sistemática recursal dos juizados especiais, implica a competência exclusiva das Turmas Recursais para a solução final das lides de menor valor em face do Estado, como órgão mais alto de julgamento

Os casos de sua competência vão desde disputas significativas de servidores públicos, que diante da grande quantidade de demandas repercute significantemente no erário, até questões tributárias ou de responsabilidade civil do Estado, apontando para um papel relevante e central a ser exercido pela Turma Recursal na formação da jurisprudência dentro de sua competência, orientando, assim, o atuar dos jurisdicionados e dos operadores do direito que, de alguma forma, estejam vinculados às matérias por ela julgadas.

Em que pese o importante papel exercido pela Turma Recursal, inclusive como órgão formador de jurisprudência, em nome de uma suposta simplicidade procedimental inerente aos Juizados Especiais não há, no Estado do Paraná, a publicação de votos divergentes em julgamentos decididos por maioria.

Esse comportamento leva à impossibilidade de compreensão, pelos jurisdicionados e operadores do direito em geral, dos rumos e transições ocorridas no âmbito de sua jurisprudência, acarretando situações de alterações abruptas de entendimento e ferindo princípios basilares do Estado de Direito, como segurança jurídica e publicidade. 
Nessa conjuntura, propõe-se demonstrar a necessidade da publicação dos votos divergentes nos julgamentos realizados pela Turma Recursal da Fazenda Pública do Paraná a partir da análise do papel por ela exercido como locus de formação jurisprudencial, da função do Judiciário como garante da segurança jurídica e da necessária formatação institucional dos órgãos para a concretização deste escopo

\section{Jurisdição no Estado Constitucional e o valor segurança jurídica}

O magistrado do Estado Constitucional contemporâneo não se limita a, simplesmente, aplicar a lei ao caso concreto. O raciocínio jurídico a ser desenvolvido na solução dos casos atualmente demanda a adequação, sempre, das normas aplicáveis às previsões constitucionais que regem o sistema jurídico como um todo. Afinal, idealmente nenhuma norma aplicada pode ir de encontro àquilo que prevê a Constituição ${ }^{1}$.

No Brasil, as repercussões dessa forma de atuação vão ainda mais além, tendo em vista o caráter excepcional de nossa Jurisdição que outorga a todos os juízes a possibilidade de revisão constitucional - controle difuso de constitucionalidade - ao mesmo tempo em que mantém uma Corte Constitucional (o Supremo Tribunal Federal) com a incumbência de realizar o controle concentrado de constitucionalidade.

Portanto, no sistema jurisdicional brasileiro o juiz singular, ao decidir os casos, tem o poder de negar vigência à lei, se violada a Constituição, ou interpretá-la de maneira a conformar a norma dela extraível às disposições constitucionais. Ainda, possível ao magistrado até mesmo suprir omissão legislativa, a fim de dar efetividade a direitos fundamentais (MARINONI, 2016, Cap. I).

O magistrado brasileiro, diante de tais possibilidades, não mais é chamado a apenas aplicar mecanicamente o texto aos fatos, mas, sim, a analisar disposições de caráter abstrato, aberto, que apenas se veem completas e finitas no caso concreto. A norma não mais se encontra

1 "Da supremacia da lei e do Parlamento, passa-se à supremacia da Constituição, que, por sua vez, vai estabelecer diretamente direitos fundamentais e individuais dos cidadãos.” (BARBOZA, 2011, p. $64)$. 
claramente no texto ${ }^{2}$ de maneira unívoca, mas depende do magistrado, na análise juntamente ao caso concreto, para ser perfectibilizada ${ }^{3}$.

Aos magistrados, assim, cumpre o papel "de eleger, como oficial, uma opção possível" (WAMBIER, 2010) dentre aquelas extraíveis do texto legal.

O forte protagonismo judicial da construção do sentido das normas faz natural que as decisões pretéritas passem a exercer papel central na orientação da conduta dos jurisdicionados, que buscam no raciocínio por meio da experiência ${ }^{4}$ compreender o sentido eleito pelo Judiciário aos textos legais, naturalmente abstratos.

Nessa conjuntura, não apenas os precedentes obrigatórios, conforme estruturados pelo Código de Processo Civil, possuem papel de relevo na atuação dos jurisdicionados, havendo ainda importante papel a ser exercido pela jurisprudência.

Tudo isso leva à necessidade de compromissos institucionais a serem cumpridos pelos magistrados, de todos os graus, com o escopo de garantir a segurança jurídica, preservando as legítimas expectativas geradas nos jurisdicionados.

Conforme leciona Humberto Ávila, o Estado Constitucional é conformado por fundamentos ${ }^{5}$ que, violados, implicam a desconsideração do ser humano como fim em si mesmo - na concepção kantiana.

Fundamentos como a dignidade humana, a liberdade, o Estado de Direito, a democracia, a Separação dos Poderes e os direitos fundamentais,

2 "Normas não são textos nem o conjunto deles, mas os sentidos construídos a partir da interpretação sistemática de textos normativos. Daí se afirmar que os dispositivos se constituem no objeto da interpretação; e as normas, no seu resultado" (ÁVILA, 2006, p. 30).

3 "Nessa medida, como não há possibilidade de se apontar previamente qual o direito aplicado ao caso, caberá ao Judiciário densificar e dar significado a estes direitos, de acordo com o contexto histórico, social, político, moral e jurídico da sociedade naquele determinado momento. A norma, portanto, não existe no texto, mas apenas no caso concreto". (BARBOZA, 2011, p. 74).

4 Conforme aponta Schauer, a diferença essencial entre raciocinar-se por meio da experiência e por meio de precedentes é a vinculação destes, e a possibilidade de não seguir o já decidido naquela. Assim, apenas quando as razões da decisão anterior, que fizeram precedente, são de aplicação cogente é que se estará a raciocinar por meio de precedentes. Da mesma forma, estando o magistrado autorizado a ignorar ou divergir do precedente, aplicando outro raciocínio ao caso similar, o raciocínio será por meio da experiência (SCHAUER, 1987).

$5 \mathrm{O}$ autor toma por fundamentos basilares do Estado Constitucional a dignidade humana, a liberdade, o Estado de Direito, a democracia, a Separação dos Poderes e os direitos fundamentais (ÁVILA, 2019, p. 11-30). 
entretanto, apenas são resguardados pelo Judiciário na medida em que este respeita os jurisdicionados como seres racionais capazes de manifestar livremente sua vontade e pautar suas ações em padrões normativos estabelecidos (ÁVILA, 2019, p. 12).

Assim, a aplicação e construção judicial do direito, na qualidade da jurisprudência como ferramenta de fechamento hermenêutico, deve contribuir para (e assegurar que) o direito seja "conhecido, compreendido, estável, não contraditório, igualitário, uniformemente aplicado, prospectivo e eficaz", de modo que o jurisdicionado não tenha sua liberdade restringida por outros meios que não a lei determinada e prévia (ÁVILA, 2019, p. 76).

Ademais, a aplicação do direito pelo julgador, para além da direta intervenção no patrimônio jurídico das partes envolvidas, reflete em todos os jurisdicionados de maneira geral. A jurisprudência tem importante papel no direito pátrio, servindo de parâmetro aos cidadãos na análise das consequências dos atos que pretendem realizar - pelo simples fato de demonstrar ao jurisdicionado o pensamento dos julgadores em questões semelhantes $^{6}$-, possuindo papel de contenção também em relação aos próprios julgadores ${ }^{7}$.

Dessa forma, não se faz suficiente, pelo julgador, a simples interpretação dos dispositivos legais em respeito a seus significados mínimos, dentro do espaço de discricionariedade hermenêutica permitida. Necessário, também, o respeito aos entendimentos consolidados acerca de tais interpretações, atuando o Judiciário como instituição, e não como a reunião de diversos juízos singulares.

Impreterível também para a preservação da liberdade do indivíduo e de sua possibilidade de autodeterminação que as mudanças de interpretação em relação aos fatos e textos jurídicos e aos critérios de

6 "In countless instances, out of law as well as in, the fact that something was done before provides, by itself, a reason for doing it that way again” (SCHAUER, 1987).

7 “Já os precedentes não vinculantes, ou melhor, a jurisprudência não vinculante consolidada de um tribunal também é fator de contenção da decisão judicial na medida em que fixa os parâmetros interpretativos a serem seguidos. Apesar de não haver obrigatoriedade de repetição do posicionamento, é certo que os juízes não gostam de ver suas decisões serem reformadas pelas instâncias superiores. Portanto, da mesma forma se torna um meio de contenção das influências não jurídicas sobre a decisão judicial, vez que operam antes de sua prolação.” (FERNANDES, 2015, p. 288). 
preenchimento de lacunas normativas sejam de seu conhecimento prévio ${ }^{8}$. Apenas assim poderá o jurisdicionado ser tido por igual não apenas $n a$ lei como também perante a lei ${ }^{9}$ e sua aplicação.

Esses fundamentos do Estado Constitucional devem sempre nortear as atividades dos julgadores e a conformação institucional dos loci de julgamento, cumprindo aos magistrados, na realização de seu labor, atuar de maneira a dar a esses fundamentos efetividade não apenas no julgamento do caso concreto, mas, também, na publicização do processo decisório realizado.

$\mathrm{O}$ atual magistrado, portanto, não mais é aquele bouche de la loi moderno francês. Entretanto, tal fato não significa a possibilidade de dar à lei qualquer interpretação, ou ignorar todas as fontes do direito a fim de dar aos casos qualquer solução, em detrimento daquelas conformadas pelo ordenamento jurídico.

\section{Formatação institucional, publicidade e segurança jurídica}

Conrado Hübner Mendes elenca três fases deliberativas enfrentadas pelo órgão colegiado durante o processo decisório até que se tenha a decisão final publicada, conforme sintetizam Botelho e Fiorindo (2016):

1) Na fase pré-decisional, a corte deve ter a capacidade de ouvir atentamente a pluralidade de argumentos que são expostos pelos diversos interlocutores, buscando compreender e ouvir ativamente o que os interlocutores têm a dizer, podendo, incidentalmente, discutir com os interlocutores a clareza e consistência dos argumentos apresentados.

2) A fase decisional corresponde ao processo interno de deliberação propriamente dito, em que os juízes debaterão os argumentos expostos pelos demais integrantes da corte, de forma séria e respeitosa e com a mente aberta às diferentes opinióes. A virtude, por ele denominada de colegialidade, ocupa lugar de destaque e tende a promover o consenso, já que decisão deixa de ser individual de cada juiz e passa a ser da corte. Significa dizer que o provimento jurisdicional da corte é fruto do

8 “Independentemente da especificação do direito fundamental ao qual esteja vinculado, o fato é que segurança jurídica resta erigida à categoria de direito fundamental, visto que se torna inviável a vida em sociedade sem saber ao certo o que esperar das qualificações jurídicas ou como pautar-se diante da coletividade, aí esta a razão de ser dos clamores sociais anteriormente citados. Diz respeito à postura do indivíduo quanto ao que esperar do Estado e dos demais indivíduos em relação ao direito estabelecido" (HENRIQUES FILHO, 2015, Cap. 37).

9 Artigo 5oㅡ, Constituição Federal. 
debate atento, sério e responsável entre os integrantes do órgão colegiado, cuja deliberação é reflexo do trabalho da corte, como um todo, e não de cada juiz isoladamente.

E, no caso de não se obter um consenso espontâneo ou uma maioria qualificada, Hübner Mendes (2013, p. 130) admite um compromisso entre os juízes da corte, fazendo com que aquele juiz que, mesmo acreditando no acerto de suas razões, releve-as em prol da decisão consensual do órgão colegiado.

3) Na fase pós-decisional, a corte deve rascunhar uma decisão deliberativa escrita, a qual deve ser clara, não apenas para a classe jurídica, porém para a comunidade política de uma forma geral. A corte ainda deve ter a consciência da falibilidade de sua decisão e de sua provisoriedade, já que há possibilidade de sua reversão no futuro. E, por fim, no que tange à "responsividade", a corte deve dar resposta adequada para os argumentos levantados pelos interlocutores na fase prédecisional, conquanto não esteja obrigada a responder a todos eles, tendo o poder de selecioná-los.

Com isso, percebe-se que a garantia da igualdade perante o direito deve passar, invariavelmente, pelas formas pelas quais se realiza a deliberação dos casos nos órgãos colegiados e pelas formas pelas quais se externaliza tal deliberação. O como se faz e - especialmente para o escopo deste trabalho ${ }^{10}$ - o como se transmite adquirem aqui especial importância.

Para a elaboração do acórdão por um órgão colegiado, há dois modelos principais que podem ser adotados: per seriatim e per curiam. Naquele, os votos de cada um dos integrantes do quórum são publicados individualmente, somando-se a fim de formar o acórdão final; neste, há a publicação de uma única decisão, que representa o voto final da corte.

Ambos os modelos de publicização das decisões possuem pontos favoráveis e $\operatorname{contrários}^{11}$; entretanto, é apenas no modelo per seriatim, na

10 Considerando que o escopo desse trabalho se encontra na análise das possibilidades institucionais de se garantir segurança jurídica e previsibilidade, por meio de uma sólida construção jurisprudencial no âmbito da Turma Recursal da Fazenda Pública do Estado do Paraná, sob a óptica do jurisdicionado e da proteção de sua confiança legitimamente suportada, analisar-se-á a forma pela qual se externaliza a deliberação - como se transmitem as opiniões do Tribunal aos jurisdicionados, seja àqueles envolvidos no caso concreto, seja aos demais interessados potencialmente atingidos pela jurisprudência firmada - não se aprofundando a análise da deliberação interna no âmbito dessa Turma Recursal.

11 "A favor do pronunciamento com publicidade do voto dissidente e per seriatim podem ser compilados os seguintes argumentos: i) confere publicidade aos votos proferidos pelos membros da corte, reforçando sua autoridade; ii) auxilia a corte a corrigir seus próprios erros; iii) ajuda a compreender melhor o julgamento e aumenta a consciência jurídica da sociedade; iv) constitui garantia para os direitos civis, além de ter um valor psicológico junto da parte sucumbente e perante os demais juízes que compartilhavam da opinião divergente; v) legitima a atuação da corte, que, de 
publicização do voto dissidente, que a corte se demonstra transparente ${ }^{12}$, possibilitando o diálogo e o prosseguimento do direito jurisprudencial.

Afinal, haverá sempre pontos em relação aos quais, em determinado momento, não seja possível a existência de unanimidade ${ }^{13}$. Em situações tais, ignorar que a dissidência existe e publicizar opiniões divididas como se únicas fossem apenas desconsidera o jurisdicionado como fim em si mesmo, tratando-o como objeto a quem pouco importa a direção a que se encaminha o entendimento do órgão.

Ademais, os pontos favoráveis do modelo de publicização per curiam, com o fortalecimento a uma aplicação posterior do precedente firmado, a facilitação da extração de uma ratio decidendi e acessibilidade de leitura do julgado mostram-se favoráveis, em face da ignorância dos votos dissidentes, quando a preocupação do julgamento está mais voltada à formação de um precedente (prospectiva), uma última palavra sobre a matéria, que à solução do caso concreto e ampliação da discussão de determinada questão.

outro modo, somente seria legitimada pelo lado vencedor; vi) possibilita a interpretação dinâmica da Constituição, deixando-a aberta para futuras interpretações; vii) promove o debate público, abrindo o diálogo entre juízes, entre esses e professores, contribuindo, ainda, para o desenvolvimento do Direito.

De outro lado, encontram-se os motivos que vão de encontro à aceitabilidade do voto dissidente e do formato per seriatim: i) os votos divergentes colocam em risco a autoridade, o prestígio e a legitimidade da corte; ii) enfraquecem a credibilidade da corte; iii) representariam um perigo à unidade e à solidariedade da corte, bem como à certeza e segurança do direito; iv) causam confusão desnecessária na compreensão do julgamento, reduzindo a força persuasiva do julgado; v) a decisão não é vista como pronunciamento final da corte, mas sim a decisão da maioria ou minoria; vi) há demora na redação final da decisão; vii) a possibilidade de voto divergente pode ser mal utilizada, sendo empregada apenas para promoção pessoal do juiz dissidente; viii) as questões constitucionais são politicamente sensíveis para se admitir votos dissidentes e, por fim, ix) o voto dissidente é totalmente desnecessário, já que não há interesse na opinião daquele juiz que ficou minoritário." (BOTELHO; FIORINDO, 2016).

12 Acerca do modelo per curiam, pontua Marçal: “Importante destacar que, não obstante esse modelo indicar as reduzidas chances de uma decisão final absolutamente não consensual, não parece que seja também isento de problemas.

Afinal, ainda se nota que existem votos divergentes e simplesmente os suprimir (ou os tornar secretos) não faz com que a deliberação seja de maior qualidade. $\mathrm{Na}$ verdade, é possível que os principais problemas existentes no método seriatim (e no case-by-case) também estejam presentes aqui; simplesmente não se sabe suas extensões, pois ficam mascarada pela opinion of the court." (MARÇAL, 2019).

13 “A existência de decisões não unânimes em órgãos colegiados é inevitável. Mais do que isso, a não unanimidade é quase uma tendência natural, especialmente em se tratando de órgãos que decidem questões moral e politicamente polêmicas." (SILVA, 2015). 
Nesse diapasão, a própria compreensão de que às Cortes superiores resta o papel de dar unidade ao direito ${ }^{14}$, por meio da formação de precedentes vinculantes ${ }^{15}$, e que aos Tribunais de Justiça compete a exploração de possíveis significados hermenêuticos dos textos normativos advoga em favor da publicização das decisões minoritárias pelos órgãos colegiados dos Tribunais de Justiça. Ora, se grande parte da contribuição dos órgãos colegiados dos Tribunais de Justiça é a exploração de possíveis significados de textos jurídicos, a não publicação de votos dissidentes obsta sobremaneira sua realização, impossibilitando aos jurisdicionados e operadores do direito o conhecimento amplo das divergências presentes no âmbito das cortes.

Pelo mais, a alteração ou superação de entendimentos no bojo de um órgão colegiado não deve ocorrer de maneira abrupta e desavisada, ainda que assim se apresente para um interlocutor mais desavisado.

Pois não raras vezes a superação de um entendimento se inicia com o acolhimento, por um dos pares, de uma nova tese apresentada em caso semelhante, ainda não analisada pelos demais que, fiéis ao entendimento já firmado, relutam em aceitá-la. Inicia-se assim um processo de convencimento que pode demorar períodos temporais variados e que, ao final, pode desembocar: (a) na confirmação do entendimento anterior, pela superação do argumento apresentado e realinhamento do par dissidente ao entendimento anteriormente firmado; (b) na superação do entendimento anterior, com o convencimento dos demais pares de que o

14 "Se é certo que as Cortes Supremas têm o dever de dar unidade ao direito mediante os seus precedentes e de torná-los pendores de segurança em nossa ordem jurídica, certamente não se passa exatamente o mesmo com as Cortes de Justiça. É claro que é desejável que a jurisprudência dos Tribunais de Justiça e dos Tribunais Regionais Federais seja uniforme e segura, assim como é evidente que essas Cortes têm - a partir da existência de precedentes sobre o caso que devem julgar - o dever de aplicá-los sem quebra de igualdade. No entanto, a função dessas cortes está ligada justamente à exploração de possíveis significados dos textos jurídicos a partir do controle da justiça do caso concreto (a interpretação do direito é apenas um meio para chegar-se ao fim controle da justiça do caso). É diferente do que ocorre com as Cortes Supremas, em que o caso concreto é apenas um meio a partir do qual se parte para chegar-se ao fim interpretação do direito. Enquanto inexiste precedente da Corte Suprema encarregada de formá-lo, o desacordo interpretativo é em grande medida inevitável, dado o caráter equívoco da linguagem em que vazados os textos legislados" (MITIDIERO, 2015).

15 Tal divisão estrita de funções entre as cortes não é unanimidade perante a doutrina nacional. Em sentido adverso: "Afirmar que a função dos Tribunais não é criar precedentes pois, segundo a Constituição Federal, cabe apenas às Cortes Supremas fazê-lo, parece um equívoco reducionista.” (HENRIQUES FILHO, 2015, Cap. 37). 
novo entendimento deve prevalecer ou; (c) na ocorrência de uma incompatibilidade insuperável de entendimentos, que só venha a ser superada com a alteração da composição do órgão, para então se confirmar ou superar entendimento anterior.

Entretanto, tais caminhos percorridos apenas poderão ser observados e compreendidos pelo jurisdicionado e demais operadores do direito se às opiniões divergentes surgidas for dada a devida consideração, com sua publicização - em uma aproximação, tomadas as devidas proporções, à técnica do anticipatory overruling performada nos países de common law ${ }^{16}$. Do contrário, a alteração de entendimento surgirá sem aviso, como se abrupta fosse.

Sob a óptica do jurisdicionado, não basta apenas que os julgadores mantenham coerência na aplicação da legislação, respeitando posicionamentos já consolidados. É imprescindível também que a alteração desses posicionamentos - pois utópico imaginar a consolidação ad eternum de posicionamentos jurídicos - se dê de maneira advertida e não abrupta, de modo a evitar a quebra de expectativas legitimamente criadas e, assim, respeitar o jurisdicionado como fim em si mesmo.

É justamente nesse sentido, inclusive, que caminha a legislação processual civil brasileira, com a inclusão do artigo 941, parágrafo 3oㅡ no Código de Processo Civil ${ }^{17}$, cujo conteúdo não era previsto no Código revogado e impõe a publicação do voto divergente conjuntamente com o voto vencedor, passando aquele a compor o conteúdo do acórdão proferido pelo colegiado.

16 “A utilização da técnica de antecipação da superação, adotada pelo menos desde 1942 pelos tribunais de apelação nos Estados Unidos, é um juízo que prenuncia a potencial queda do precedente, haja vista que se apresentam fundamentos idôneos que levarão, em perspectiva, à sua superação pelo tribunal que o estabeleceu" (JOBIM; DUARTE, 2018).

17 Art. 941. Proferidos os votos, o presidente anunciará o resultado do julgamento, designando para redigir o acórdão o relator ou, se vencido este, o autor do primeiro voto vencedor.

$\S 1$ o O voto poderá ser alterado até o momento da proclamação do resultado pelo presidente, salvo aquele já proferido por juiz afastado ou substituído.

$\S 2$ o No julgamento de apelação ou de agravo de instrumento, a decisão será tomada, no órgão colegiado, pelo voto de 3 (três) juízes.

§ 3o O voto vencido será necessariamente declarado e considerado parte integrante do acórdão para todos os fins legais, inclusive de pré-questionamento. 
Tal inovação, por mais que em parte seja voltada ao enfrentamento da assim chamada "jurisprudência defensiva" das Cortes de Vértice ${ }^{18}$, demonstra o amadurecimento da organização judiciária brasileira, oportunizando a real compreensão das divergências ocorridas no âmbito dos órgãos colegiados e da direção a que caminha seu entendimento, contribuindo para a legitimidade democrática das decisões judiciárias ${ }^{19}$, conforme expressado pelo Superior Tribunal de Justiça ao analisar o referido dispositivo:

“4. A razão de ser do § 3 do art. 941 do CPC/15 está ligada, sobretudo, à exigência de fundamentação, inerente a todas as decisões judiciais, nos termos do art. 93, IX, da Constituição Federal e, em consequência, à observância do direito fundamental ao devido processo legal, na medida em que, na perspectiva endoprocessual, a norma garante às partes o conhecimento integral do debate prévio ao julgamento, permitindo o exercício pleno da ampla defesa, e, na perspectiva extraprocessual, confere à sociedade o poder de controlar a atividade jurisdicional, assegurando a independência e a imparcialidade do órgão julgador." (REsp 1729143/PR, Rel. Ministra NANCY ANDRIGHI, TERCEIRA TURMA, julgado em 12/02/2019, DJe 15/02/2019.)

Ademais, jurisprudência não se constrói por meio do somatório de ementas e conclusões, mas pelo conjunto de razões reiteradamente adotadas por um órgão judiciário. Se jurisprudência é um entendimento constante e uniforme de um tribunal sobre determinada questão jurídica ${ }^{20}$ e se, para que se possa extrair de uma decisão lições aplicáveis a casos

18 A exemplo, temos a Súmula no 320, do Superior Tribunal de Justiça, que assim dispõe: "A questão federal somente ventilada no voto vencido não atende ao requisito do prequestionamento."

19 “O mesmo ocorre no cotidiano forense. Cada magistrado, ao interpretar, atribuiu um sentido próprio ao Direito. Esse fato constitui uma das premissas do ordenamento jurídico brasileiro e, ao menos no Estado Democrático de Direito, não pode ser totalmente afastada. É justamente por isso que se permite aos julgadores a divergência nos julgamentos colegiados. Parece ser correta a afirmação de que a divergência contribuiu para a legitimidade democrática de uma decisão do Poder Judiciário, justamente por permitir que mais de um olhar seja lançado sobre uma determinada situação jurídica." (KOSIKOSKI; PUGLIESE, 2018).

20 “"Chama-se Jurisprudência, em geral, ao conjunto das soluções dadas pelos tribunais às questões de Direito; relativamente a um caso particular, denomina-se jurisprudência a decisão constante e uniforme dos tribunais sobre determinado ponto do Direito." (...) Veja-se que nada obstante estejamos tratando da valorização das decisões pretéritas, a constatação não vem em detrimento da importância das leis, ou regras e princípios positivados, além de elementos não textuais do Direito, como pode ser o próprio costume. Antes disso, a preocupação, ao menos inicial, é justamente uniformizar a interpretação ou aplicação concreta desse Direito, algo que vem muito a propósito das raízes históricas aqui existentes." (MARIANI, 2018, p. 54). 
posteriores, devem ser analisadas as razões utilizadas pelos magistrados para a adoção das conclusões extraídas, a simples utilização de ementas não supre a necessidade de fundamentação. ${ }^{21}$

Em um ambiente em que a jurisprudência deve ser considerada, a publicação dos votos divergentes no julgamento colegiado de casos é indispensável à sua correta aplicação.

Portanto, para que o jurisdicionado e os operadores do direito em geral tenham a possibilidade de agir em conformidade com o direito interpretado pelo Judiciário, bem como possam satisfatoriamente prever a direção na qual caminha a jurisprudência, seja por meio de sua consolidação, seja por meio de sua superação - e reste assim preservada sua dignidade e respeitada sua liberdade de livremente direcionar suas escolhas de vida - os Tribunais, as Cortes Supremas e os órgãos de primeiro grau de Jurisdição, dentro de suas devidas competências, devem se conformar institucionalmente de maneira a propiciar o diálogo entre os agentes que participam do processo decisório e viabilizar o conhecimento do caminho já percorrido e da tendência de caminhos a se percorrer. $\mathrm{O}$ desenho institucional importa.

\section{Turma Recursal da Fazenda Pública, jurisprudência e publicação do voto divergente}

Os juizados especiais da Fazenda Pública, no âmbito da Justiça Comum Estadual, foram instituídos pela Lei 12.153/09, que regula seu o procedimento e sua competência.

Trata-se de lei que bastante se assemelha à lei dos Juizados Especiais Federais (Lei 10.259/01), muito em razão da grande semelhança das partes envolvidas - Estado e suas autarquias e fundações como demandados.

21 “As razões pelas quais a maioria de um colegiado se posicionou em determinado sentido só são compreendidas com a leitura da íntegra do julgamento, uma vez que a ementa deixa explícito apenas o que corresponderia, em uma sentença, ao dispositivo. E ementa "sintetiza a tese jurídica adotada no julgamento", por meio das razões de decidir explicitadas pelo relator. E, no respeito à correta compreensão da força normativa (= eficácia de precedente) do direito jurisprudencial, importam muito mais os motivos, até mesmo para o exercício de universalização pelo intérprete futuro, do que o decisum em si” (SCHMITZ; ALVIM, 2015, Cap. 24). 
Em relação à sua competência, diante da redação do parágrafo 4으o do artigo $2^{\underline{0}}$ da Lei $12.153 / 09^{22}$, diversas discussões surgiram quanto à extensão da competência absoluta às causas cujo valor esteja enquadrado no limite legal, mas cuja complexidade probatória ou jurídica seja incompatível com o rito sumaríssimo dos juizados especiais.

Constitui debate quanto aos dois critérios elencados pelo inciso I do artigo 98 da Constituição Federal para a criação dos juizados especiais: causas de pequena expressão econômica e causas de pequena complexidade..$^{23}$

Sobre a questão, o Tribunal de Justiça do Estado do Paraná, por meio da Seção Cível Ordinária, e em observância à jurisprudência que se constrói perante o Superior Tribunal de Justiça acerca da matéria - iniciada em relação aos Juizados Especiais Federais ${ }^{24}$ e mantida após a promulgação da Lei $12.153 / 09^{25}$-, firmou entendimento ${ }^{26}$ no sentido de que a competência dos Juizados Especiais da Fazenda Pública é absoluta nas comarcas em que instalado, independentemente da complexidade da causa.

22 Art. 2o É de competência dos Juizados Especiais da Fazenda Pública processar, conciliar e julgar causas cíveis de interesse dos Estados, do Distrito Federal, dos Territórios e dos Municípios, até o valor de 60 (sessenta) salários mínimos.

(..)

$\S 40$ No foro onde estiver instalado Juizado Especial da Fazenda Pública, a sua competência é absoluta.

23 "Há, portanto, previsão constitucional para criação de juizados de menor complexidade e de juizados de pequenas causas. Aqueles não se confundem com estes. Não se trata de nomes diferentes para o mesmo órgão jurisdicional. A Constituição Federal prevê a possibilidade de criação de juizados para causas de pouca complexidade, independentemente do valor envolvido, bem como de juizados destinados a causas de pequeno valor econômico." (CUNHA, 2009).

24 A título de exemplificação: "Os Juizados Especiais Federais possuem competência para o julgamento das ações de fornecimento de medicamentos em que haja litisconsórcio passivo necessário entre a União, o Estado e o Município, cujo valor da causa não exceda sessenta salários mínimos, sendo desinfluente o grau de complexidade da demanda ou o fato de ser necessária a realização de perícia técnica" (AgRg no Resp 1.222.345/SC, Rel. Ministro Hamilton Carvalhido, Dje de $18 / 2 / 2011)$.

25 A exemplo, resumindo o entendimento da Corte: "2. A jurisprudência desta Corte entende que a competência dos Juizados Especiais deve ser fixada segundo o valor da causa, que não pode ultrapassar 60 salários mínimos, sendo irrelevante a necessidade de produção de prova pericial, ou seja, a complexidade da matéria." (AgInt no AREsp 572.051/RS, Rel. Ministro NAPOLEÃO NUNES MAIA FILHO, PRIMEIRA TURMA, julgado em 18/03/2019, DJe 26/03/2019)

26 Acórdão paradigma prolatado pela Seção Cível Ordinária do TJPR no âmbito do IAC no 1711920-9/01, em seção de 14.06.2019, com relatoria do Desembargador Carlos Mansur Arida. 
Trata-se de conclusão em consonância com os dispositivos legais aplicáveis à espécie, tendo o legislador adotado o valor da causa como critério de expressão da pouca complexidade, para fins de enquadramento das lides no inciso I do artigo 98 da Constituição Federal, ainda que ignorando a possibilidade de que existam questões complexas - em sentido jurídico ou probatório - com pouca ou nenhuma expressividade econômica e que estarão, inequivocamente, subordinadas aos Juizados Especiais da Fazenda Pública.

O entendimento firmado pelo Superior Tribunal de Justiça, e ratificado pelo Tribunal de Justiça do Estado do Paraná, implica consequência clara, mas não tão evidente: uma miríade de questões jurídicas estará subordinada unicamente ao conhecimento dos Juizados Especiais da Fazenda Pública.

Afinal, questões que não se enquadrem em nenhum dos incisos do parágrafo $1^{\circ}$ do artigo $2^{\circ}$ da Lei $12.153 / 09$, cujos autores não sejam pessoas jurídicas e que necessitem de prova pericial estarão impossibilitadas de serem conhecidas por meio do Mandado de Segurança.

Tais casos terão apenas o valor da causa a determinar a competência - absoluta - para seu julgamento, sendo, portanto, direcionados aos Juizados Especiais da Fazenda Pública.

Isso implica, também, a aplicação da sistemática recursal própria dos Juizados Especiais da Fazenda Pública a essas causas, sendo as sentenças e decisões de questões liminares ${ }^{27}$ direcionadas à Turma Recursal competente - atualmente a $4^{\mathrm{a}}$ Turma Recursal dos Juizados Especiais do $\mathrm{TJPR}^{28}$.

A 4 $4^{\text {a }}$ Turma Recursal paranaense teve distribuídos entre seus pares, nos últimos três anos, 40.308 (quarenta mil trezentos e oito) recursos oriundos de Varas dos Juizados Especiais da Fazenda Pública, em uma média de 13.436 (treze mil quatrocentos e trinta e seis) recursos distribuídos por ano ${ }^{29}$. Tais são os números apenas dos processos que

27 Artigos 3ํㅜ e $4^{\circ}$, Lei 12.153/09.

28 Artigo 17, Lei 12.153/09; art. 2º , inciso II, Resolução no 235/2019 do Órgão Especial do TJPR.

29 Conforme relatório disponível no Sistema Projudi, pelo qual tramitam todos os processos perante as Turmas Recursais do Paraná, no ano de 2017 foram distribuídos aos magistrados que compõem 
tiveram decisões e sentenças recorridas e os respectivos recursos distribuídos.

Percebe-se que, por mais que as causas que tramitam perante os Juizados Especiais da Fazenda Pública sejam de menor expressão econômica (limitadas a 60 salários-mínimos), o conjunto de todas as demandas pode ter reflexos significativos ao erário.

Para além da questão econômica, exsurge o viés orientador (prospectivo) da atuação da Turma Recursal responsável por tais julgamentos. Afinal, um órgão colegiado que decide mais de dez mil recursos por ano em face de Estado, Municípios e respectivas autarquias e fundações torna-se, invariavelmente, um órgão formador de jurisprudência, independentemente de eventual reduzido valor econômico ou objetividade na fundamentação de seus arestos.

O papel de turma formadora de jurisprudência pode ser ainda reforçado diante de específicos fatores introduzidos pela sistemática dos Juizados Especiais da Fazenda Pública.

No âmbito dos Juizados Especiais, muito em razão do rito sumaríssimo constitucionalmente exigido (inciso I do artigo 98 da Constituição Federal), as hipóteses recursais foram reduzidas ao máximo. Assim, cabem recursos à Turma Recursal, no âmbito dos Juizados Especiais da Fazenda Pública, apenas em face de sentença e decisão que analise pedido liminar (artigo $4^{\circ}$ da Lei 12.153/09).

Já das decisões proferidas pela Turma Recursal será cabível, como recurso, apenas o Recurso Extraordinário, nos termos do inciso III do artigo 102 da Constituição Federal e Súmula 640 do Supremo Tribunal Federal, a fim de dirimir controvérsias constitucionais.

Por outro lado, quanto a questões infraconstitucionais, as possibilidades tornam-se mais restritas.

Diante da redação do inciso III $^{30}$ do artigo 105 da Constituição Federal que traz "Tribunais Regionais Federais ou pelos tribunais dos Estados",

a 4 $4^{\text {a }}$ Turma Recursal 10.246 recursos oriundos de processos que tramitaram pelo rito da Lei 12.153/09. Em 2018, foram distribuídos 15.891 e, em 2019, 14.171.

30 Art. 105. Compete ao Superior Tribunal de Justiça:

$(\ldots)$ 
diferentemente do inciso III ${ }^{31}$ do artigo 102, onde se lê "em única ou última instância", o Superior Tribunal de Justiça firmou o entendimento de que é incabível a interposição de Recurso Especial em face de acórdão de Turma Recursal pois, uma vez composta por magistrados de primeiro grau, não se enquadraria no conceito de "tribunais". O entendimento restou consolidado com a elaboração da Súmula 203 do STJ ${ }^{32}$.

Ademais, ainda que possível fosse a interposição de recursos ao STJ, e mesmo com a possibilidade de interposição de Recurso Extraordinário ao STF, grande parte das questões dirimidas nos Juizados Especiais da Fazenda Pública dos Estados tratam de direito local (estadual e municipal), de modo que esbarram em entendimentos consolidados por ambas as Cortes de Vértice quanto à impossibilidade de interposição de recursos a elas em caso de violação dessas matérias, conforme Súmula 13 do STJ ${ }^{33}-$ tendo em vista que fatalmente inexistirá divergência entre tribunais distintos em relação a direito local - e Súmula 280 do $\mathrm{STF}^{34}$.

III - julgar, em recurso especial, as causas decididas, em única ou última instância, pelos Tribunais Regionais Federais ou pelos tribunais dos Estados, do Distrito Federal e Territórios, quando a decisão recorrida:

a) contrariar tratado ou lei federal, ou negar-lhes vigência;

b) julgar válido ato de governo local contestado em face de lei federal;

c) der a lei federal interpretação divergente da que lhe haja atribuído outro tribunal.

31 Art. 102. Compete ao Supremo Tribunal Federal, precipuamente, a guarda da Constituição, cabendo-lhe:

$(\ldots)$

III - julgar, mediante recurso extraordinário, as causas decididas em única ou última instância, quando a decisão recorrida:

a) contrariar dispositivo desta Constituição;

b) declarar a inconstitucionalidade de tratado ou lei federal;

c) julgar válida lei ou ato de governo local contestado em face desta Constituição.

d) julgar válida lei local contestada em face de lei federal.

32 Súmula 203-STJ: Não cabe recurso especial contra decisão proferida por órgão de segundo grau dos Juizados Especiais.

33 Súmula 13-STJ: A divergência entre julgados do mesmo tribunal não enseja recurso especial.

34 Súmula 280-STF: Por ofensa a direito local não cabe recurso extraordinário. 
Ainda, incabível a ação autônoma de Reclamação ao Superior Tribunal de Justiça no âmbito dos Juizados Especiais da Fazenda Pública, conforme fixado pela Corte no julgamento da Reclamação 22.033/SC ${ }^{35}$.

Afora o Recurso Extraordinário, surge como possibilidade de revisão das decisões da Turma Recursal o Pedido de Uniformização de Interpretação de Lei (PUIL), nos casos previstos no artigo 18 da Lei $12.153 / 09^{36}$. O PUIL será direcionado ao Tribunal de Justiça ao qual vinculadas as Turmas Recursais, em caso de divergência entre Turmas do mesmo Estado - o que demanda uma pluralidade Turmas Recursais da Fazenda Pública no mesmo Estado, que não ocorre no Estado do Paraná , ou ao Superior Tribunal de Justiça, quando ocorrer divergência de interpretação de lei federal entre Turmas Recursais de diferentes Estados ou quando houver decisão contrária a Súmula do próprio STJ.

Trata-se de hipóteses restritas, e que abarcam apenas uma pequena parte das controvérsias submetidas aos Juizados Especiais da Fazenda Pública - apenas aquelas que envolvam controvérsia em relação a lei federal e à Constituição.

35 “(...) 1. O sistema para processo e julgamento de causas em juizados especiais é composto por três microssistemas: a) Juizados Especiais Estaduais Comuns - instituídos pela Lei n. 9.099/1995; b) Juizados Especiais Federais - instituídos pela Lei n. 10.259/2001 e; c) Juizados Especiais da Fazenda Pública Estadual e Municipal - instituídos pela Lei n. 12.153/2009. Cada um deles é submetido a regras específicas de procedimento, inclusive com relação ao mecanismo de uniformização de jurisprudência e de submissão das decisões das Turmas Recursais ao crivo do Superior Tribunal de Justiça.

\section{(...)}

4. Finalmente, quanto ao microssistema dos Juizados Especiais da Fazenda Pública instituídos pela Lei n. 12.153/2009 é cabível o pedido de uniformização de jurisprudência, nas hipóteses dos arts. 18 e 19 da Lei n. 12.153/2009, ou seja, quando: a) as Turmas de diferentes Estados derem a lei federal interpretações divergentes ou; b) a decisão proferida estiver em contrariedade com súmula do Superior Tribunal de Justiça.” (Rcl 22.033/SC, Rel. Ministro MAURO CAMPBELL MARQUES, PRIMEIRA SEÇÃO, julgado em 08/04/2015, DJe 16/04/2015).

36 Art. 18. Caberá pedido de uniformização de interpretação de lei quando houver divergência entre decisões proferidas por Turmas Recursais sobre questões de direito material.

§ 1o O pedido fundado em divergência entre Turmas do mesmo Estado será julgado em reunião conjunta das Turmas em conflito, sob a presidência de desembargador indicado pelo Tribunal de Justiça.

$\S 2$ o No caso do $\S 1$, a reunião de juízes domiciliados em cidades diversas poderá ser feita por meio eletrônico.

§ 3o Quando as Turmas de diferentes Estados derem a lei federal interpretações divergentes, ou quando a decisão proferida estiver em contrariedade com súmula do Superior Tribunal de Justiça, o pedido será por este julgado. 
Dessa forma, tem-se em que na grande maioria das ações propostas dentro desse microssistema a Turma Recursal da Fazenda Pública será a última instância a apreciar a lide - e a dar palavras finais à controvérsia.

E é justamente diante de cenário tal que a Turma Recursal da Fazenda Pública surge como locus de formação de jurisprudência ${ }^{37}$. Afinal, as decisões por ela prolatadas são definitivas em grande parte das controvérsias e os entendimentos ali firmados - e eventualmente alterados - reverberam diretamente no direito pretendido pelas partes em face do Estado.

Será natural, assim, que as partes passem a adequar seus comportamentos, confiando na sua permanência, aos entendimentos firmados pelo órgão acerca das matérias a ele submetidas.

Nessa conjuntura, antecipar os rumos hermenêuticos traçados pela Turma Recursal se faz de suma importância, sob pena de o jurisdicionado ver-se surpreendido por interpretações inéditas e contrárias a qualquer expectativa legitimamente criada.

Entretanto, para que se possa ter ciência dos rumos a serem tomados pelo órgão, não basta apenas ter ciência das decisões unânimes. Em regra, é nos julgamentos em que dividido o quórum que se vislumbra o início da alteração de entendimento. E essas informações apenas são repassadas ao jurisdicionado por meio do voto divergente.

Ocorre que, atualmente, a $4^{\mathrm{a}}$ Turma Recursal do Estado do Paraná, responsável pelo julgamento dos recursos oriundos das Varas dos Juizados Especiais da Fazenda Pública paranaenses, possui entendimento de que a publicação do voto vencido se faz medida desnecessária e supérflua para a

37 A importância de que as Turmas Recursais mantenham sua jurisprudência íntegra e coerente é, inclusive, reforçada pela Resolução 02/2019 - CSJE (Regimento Interno das Turmas Recursais dos Juizados Especiais Cíveis, Criminais e Fazenda Pública do Estado do Paraná), que prevê procedimentos internos a fim de que seja a jurisprudência assim mantida (arts. 28 a 31). 
sistemática dos Juizados Especiais, inexistindo dever de sua publicação pelo órgão, ante a ausência de previsão legal expressa para tanto ${ }^{38} 39$.

Nada obstante, a simples inexistência de previsão de publicação do voto não deve ser tomada, de pronto, como silêncio eloquente do legislador. Afinal, no que for aplicável e, principalmente, no que venha a dar maior concretude aos princípios processuais constitucionais e à eficiência judicial, não há óbice à adoção, pelos Juizados Especiais, de normas insculpidas no Código de Processo Civil. ${ }^{40}$

Independentemente do acerto ou desacerto das decisões tomadas pela Turma, o fator surpresa decorrente da não publicação dos votos divergentes constitui, em si mesmo, grave violação às partes na qualidade de seres racionais que pautam suas condutas conforme o direito, ou, mais precisamente, conforme o direito interpretado pelas Cortes.

Imperioso, assim, que a Turma Recursal publique seus votos divergentes, garantindo com isso a necessária segurança jurídica e conformando-se a seu papel de locus jurisprudencial.

\section{Conclusão}

Diante das premissas adotadas no presente trabalho, conclui-se que, seja em razão do alinhamento do direito positivo a uma cultura de valorização da decisão pretérita e da divergência (artigo 941, §3ํㅡㄴ, do CPC), seja em razão do valor, em si mesmo, da previsibilidade e da coerência dos

38 EMBARGOS DE DECLARAÇÃO. OMISSÃO, EQUÍVOCO E CONTRADIÇÃO. INOCORRÊNCIA. PAGAMENTO INTEGRAL DAS HORAS EXTRAS. MERO INCONFORMISMO. DEMONSTRAÇÃO CLARA DAS RAZÕES QUE FORMARAM O CONVENCIMENTO DO ÓRGÃO JULGADOR. COMPLEMENTAÇÃO DO ACÓRDÃO COM O VOTO VENCIDO DO JULGAMENTO. DESCABIMENTO. AUSÊNCIA DE PREVISÃO LEGAL. INUTILIDADE DO PLEITO. VERBAS DE SUCUMBÊNCIA. FIXAÇÃO NOS LIMITES DO ART. 55 DA LEI № 9.099/95. EMBARGOS CONHECIDOS E REJEITADOS. (TJPR - 4⿳a Turma Recursal - 0002283-72.2017.8.16.0165 - Telêmaco Borba - Rel.: Juíza Manuela Tallão Benke - J. 28.02.2019).

39 No âmbito dos Juizados Especiais Federais do Estado do Paraná, vinculados ao Tribunal Regional Federal da 4a Região, também há entendimento no sentido de que inexistente a necessidade da publicação do voto divergente em caso de julgamento não unânime. A exemplo, vide: Recurso no 5000595-38.2019.4.04.7003, PRIMEIRA TURMA RECURSAL DO PR, Relator GERSON LUIZ ROCHA, julgado em 13/02/2020.

40 "Seja como for, havendo lacuna legislativa dentro da sistemática dos juizados e sendo a norma no diploma geral compatível com os ideais que norteiam o microssistema, é imperiosa a aplicação do CPC” (NÓBREGA, 2017). 
sistemas jurídicos, ou ainda em razão das graves consequências práticas nos direitos tutelados, à Turma Recursal da Fazenda Pública do Estado do Paraná, na qualidade de órgão formador de jurisprudência - e, assim, de atuação também prospectiva -, se impõe a publicação dos votos divergentes, a fim de dar aos jurisdicionados e aos operadores do direito em geral o ferramental necessário à correta orientação de suas ações e escolhas.

\section{Referências bibliográficas}

ÁVILA, Humberto. Teoria dos princípios: da definição à aplicação dos princípios jurídicos. 5. ed. São Paulo: Malheiros editores, 2006.

ÁVILA, Humberto. Constituição, liberdade e interpretação. São Paulo: Malheiros Editores, 2019.

BARBOZA, Estefânia Maria de Queiroz. Stare decisis, Integridade e Segurança Jurídica: Reflexões Críticas a Partir da Aproximação dos Sistemas de Common Law e Civil Law na Sociedade Contemporânea. 2011. Tese (Doutorado em Direito) - Faculdade de Direito, Pontifícia Universidade Católica do Paraná, Curitiba, 2011.

BOTELHO, Cristiane Miranda. FIORINDO, Regivano. Deliberação nas cortes superiores. Julgamento per seriatim e per curiam. Importância da fixação da ratio decidendi. Delineamento de técnicas processuais de distinção - distinguishing. Exame de caso paradigmático julgado pela turma nacional de uniformização dos juizados especiais federais. Revista de Processo, v. 258, p. 317-340, 2016.

CUNHA, Leonardo José Carneiro da. Anotações sobre a competência dos Juizados Especiais Cíveis Federais. Revista de Processo, v. 173, p. 33-53, 2009.

FERNANDES, Ricardo Vieira de Carvalho. Influências extrajurídicas sobre a decisão judicial - objetividade, previsibilidade e determinação. Belo Horizonte: Fórum, 2015.

HENRIQUES FILHO, Ruy Alves. O IRDR e a formação dos precedentes qualificados no Brasil. In: NUNES, Dierle. JAYME, Fernando Gonzaga. MENDES, Aluisio (Coord.). A nova aplicação da jurisprudência e precedentes no Código de Processo Civil/2015 - Estudos em homenagem à Professora Teresa Arruda Alvim. São Paulo: Revista dos Tribunais, 2015. E-Book.

JOBIM, Marco Félix. DUARTE, Zulmar. Ultrapassando o precedente: anticipatory overruling. Revista de Processo, v. 285, p. 341-362, 2018. 
KOZIKOSKI, Sandro Marcelo. PUGLIESE, William Soares. Considerações sobre a ampliação do quórum no julgamento da apelação. Revista de Processo, v. 276, p. 237-261, 2018.

MARÇAL, Felipe Barreto. Contraditório, fundamentação e técnica de julgamento colegiado: violação do contraditório (e ao dever de fundamentação), da isonomia, da previsibilidade e da segurança jurídica com o sistema de "votação global". Revista de Processo, v. 290, p. 247-275, 2019.

MARIANI, Rômulo Greff. Precedentes na arbitragem. Belo Horizonte: Fórum, 2018.

MARINONI, Luiz Guilherme. Precedentes Obrigatórios. 5. ed. São Paulo: Revista dos Tribunais, 2016. E-book.

MITIDIERO, Daniel. Precedentes, Jurisprudência e Súmulas no Novo Código de Processo Civil Brasileiro. Revista de Processo, v. 245, p. 333-349, 2015.

NÓBREGA, Rafael Estrela. O novo Código de Processo Civil e os Juizados Especiais Cíveis: aplicação subsidiária, supletiva e o diálogo das fontes. Revista de Processo, v. 271, p. 341-365, 2017.

SCHAUER, Frederick. Precedent. Stanford Law Review, v. 39, n. 3, p. 571-605, 1987.

SCHMITZ, Leonard Ziesemer. ALVIM, Arruda. Ementa. Função indexadora. (Ab)uso mecanizado. Problema hermenêutico. In: NUNES, Dierle. JAYME, Fernando Gonzaga. MENDES, Aluisio (Coord.). A nova aplicação da jurisprudência e precedentes no Código de Processo Civil/2015 - Estudos em homenagem à Professora Teresa Arruda Alvim. São Paulo: Revista dos Tribunais, 2015. E-Book.

SILVA, Virgílio Afonso da. De quem divergem os divergentes: os votos vencidos no Supremo Tribunal Federal. Revista Direito, Estado e Sociedade, v. 47, p. 205$225,2015$.

WAMBIER, Teresa Arruda Alvim. Interpretação da lei e de precedentes: civil law e common law. Revista dos Tribunais, v. 893, p. 33-45, 2010.

Submissão: 08 de novembro de 2020

Aceite: 16 de fevereiro de 2021 
Autoria:

Heloisa Führ Bonamigo helobonamigo@hotmail.com

Mestranda em Direito das Relações Sociais pela Universidade Federal do Paraná. Especialista em Direito Civil e Empresarial pela PUCPR. Graduada em Direito pela Universidade Federal do Paraná. Advogada.

Leonardo Catto Menin leocmenin@gmail.com

Mestrando em Filosofia e Teoria Geral do Direito pela Universidade de São Paulo. Pós-graduado em Direito Aplicado pela Escola da Magistratura do Paraná. Graduado em Direito na Universidade Federal do Paraná.

\section{Como citar este documento:}

BONAMIGO, Heloisa Führ; MENIN, Leonardo Catto. Turma Recursal da Fazenda Pública do Paraná como locus de formação de jurisprudência e o dever de publicação do voto divergente. Revista Eletrônica do CEJUR, v. 2, n. 5, set/dez 2020. doi:http://dx.doi.org/10.5380/cejur.v2i5.77775. 